AL-AZHAR UNIVERSITY

BULLETIN OF THE FACULTY OF

LANGUAGES \& TRANSLATION

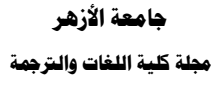

The Gender Code of Hausa Emotional Expressions

Ummulkhair Aminu Dantata

Bayero University Kano
Aisha Umar Adamu

Aminu Kano College

Islamic and Legal Studies
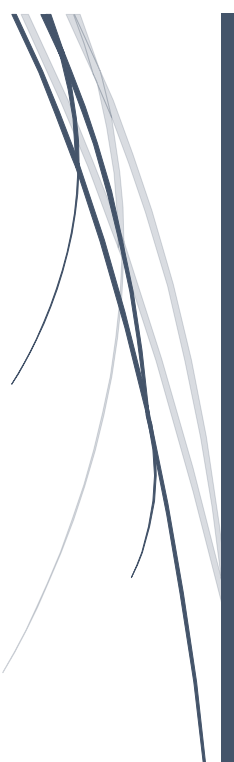


\section{THE GENDER CODE OF HAUSA EMOTIONAL EXPRESSIONS}

Ummulkhair Aminu Dantata*, Aisha Umar Adamu

Bayero University Kano, Kano State, Nigeria.

Corresponding Auther E-mail:uad7@hotmail.com

\section{Abstract:}

This paper studies the impact of gender on the expression of emotion of the Hausa people. Data were collected through observation and video recording of naturally occurring face-to face interactions, which were gathered from different interactional settings. Moreover, elicitation interviews were also conducted. Conversational Analysis serves as the framework. The findings suggest that gender has a huge impact on the way and manner Hausa people makes use of emotional expressions.

Keywords: Gender Code, Expressions, Emotion, Hausa Language, Conversational Analysis.

$$
\begin{aligned}
& \text { رمزية النوع في التعبيرات العاطفية في لغة الهوسا } \\
& \text { أم الخير أمينو داتتاتا*، عائشة عمر آدامو } \\
& \text { جامعة بايرو كانو ، ولاية كانو ، نيجيريا. } \\
& \text { البريد الإلكتروني للمؤلف الرئيسي: uad7 @ hotmail.com }
\end{aligned}
$$

الملخض:

يتناول هذا البحث تأثير النوع على التعبيرات العاطفية لشعب الهوسا. وقد تم جمع المادة العلمية المستخدمة في البحث بدراسة

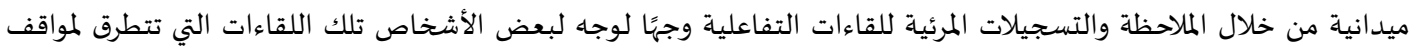

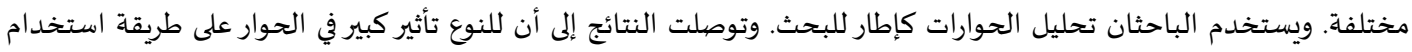
شعب الهوسا للتعبيرات العاطفية الكلمات المفتاحية: رمزية النوع، التعبيرات، العاطفة، لغة الهوسا، تحليل الحوار. 


\subsection{Introduction}

According to Hochschild (1990), gender code is a body of rules about how to look, behave and feel as a woman and as a man. Therefore, gender may influence both verbal and nonverbal means of communication, by shaping the way men and women express emotions as Adler \& Proctor II (2011) noted, we feel, think and communicate emotions. The study of emotional expressions stems interest from so many disciplines, such as psychology, sociology, semiotics, linguistics and linguistic anthropology. However, the current research is more interested in the communicative aspect, precisely, the impact of gender on emotional expressions using Conversational Analysis as its framework. This is in line with the view of researchers (Perakyla \&Sorjonen 2009, Pepin 2008 and Ruusuvuori \& Perakyla 2009) that any study concerning emotional expression requires an examination of the details of interaction.

Previous works conducted on Hausa nonverbal communication (see Olofson (1974), Yakasai (2011), Mu'azu (2013), Will (2009, 2011, 2016, 2017), Azare (2014) demonstrated that only a little attention is given to the study of emotional expression in Hausa. However, using data collected from film context, Will (2015) demonstrates how Hausa women use gestures and indirect statements to express emotions and make their opinions known. The present study is quite different from Will's in both scope and mode of data collection in the sense that, both Hausa males and females have been taken into cognisance while the data were collected through recording and observation of naturally occurring face-to face interactions gathered from multiple settings, such as wedding event, sallah and maulud ceremonies. Other data were collected from some school settings, street corner chats, family interactions, and activities in market places as well as some instances in hospitals within Kano metropolitan. Elicitation interviews were also conducted.

\subsection{Emotional Expressions}

Emotional expressions are sometimes referred to as affect displays. They are among the five categories of gestures identified by Ekman (2004). The other four being: emblems, regulators, illustrators and manipulators with each having a specified function, usage and coding. As human beings we get angry and happy. At times fear may overcome us, and we may even get ashamed or anxious. How we express and handle our emotions may impact our interactions and even our relationships. Emotional expressions are therefore, voluntary and involuntary signals which provide important information to others. For instance, in Hausa a gaze by a mother to her child can signal him or her whether she is happy or unhappy with them talking to a stranger and at the same time communicate to him whether to accept a 
gift or not. This shows that some emotions are produced voluntarily, and their meanings depend on context because they are produced with the intention to communicate and their meaning is known by speakers of a given language, in this case Hausa. This is also the view of scholars like Parkinson (2005) and Scarantino (2017).

Emotional expression is a universal phenomenon. Every culture expresses emotions. Scholars agree that there are universal ways of expressing emotions. Ekman (1992) mentioned six, namely: enjoyment, anger, sadness, disgust, fear and surprise. However, how these emotions are managed according to contexts, is dependent on individual cultures. For instance, sállàallámii ${ }^{l}$ (striking the hand while invoking the name of God) is used by Hausa women to show sadness or shock. The Chinese scratch their ears and cheeks to express happiness. Moreover, there are certain emotions unique to cultures for instance, kúnyòa (bashfulness) in Hausa influences the way Hausa people behave and is expressed via different gestures and mannerisms that may not be found in some languages.

\subsection{The Channels of Emotional Expression}

Emotions can be expressed nonverbally across three major channels namely: facial expressions, posture/ bodily cues and vocalic cues (Ekman, 2004:45).

\section{Facial Expression}

It is a common phenomenon for individuals to express their feelings by the use of the face. Hausa people have a saying labarin zuciya a tambayi fuska meaning: the face gives an insight into the mind. That is why the face is considered as the primary site for the expression of emotions in Hausa. People rely on it to display the emotional signals sent even through other channels. The face serves as the last resort concerning emotional communication. For instance, in Hausa putting the hands on the head is a gesture that signifies helplessness, usually done when something bad happens to a person. The face of the person that exhibits such gesture would no doubt exhibit the same feeling. It will not be possible for the face to echo a different feeling, such as a smile or laughter. In that case, the interpretation given to that gesture will change totally.

\footnotetext{
${ }^{11}$ All tones are marked. High tone is marked with an acute accent $/ 2$, low tone with a grave accent $/ /$ and falling tone with a circumflex $/ \wedge /$ over the nucleus of the tone bearing unit. Long vowels are doubled while short vowels are left as they are. Only words referring to nonverbal regulators will follow this format.
} 


\section{Posture and Bodily Cues}

Emotions can also be identified by locomotive and non locomotive movements of the body involving the way a person sits, stands or walks. For instance, when a person sits and uses his two hands or one to support his face it is called tàagúmíi in Hausa signifying sadness or sorrow. Although, a person may like to exhibit the gesture as a comfortable way of sitting, but, once he is seen exhibiting such a posture, the first question he may be asked is, 'What is wrong?' Arguably, tòagúmii is a gesture people are discouraged from performing with or without a reason.

\section{Vocalic Cues}

Emotions could be detected by individuals via the interlocutor's voice. Vocal properties, such as the pitch, tone, intonation, resonance convey various meanings regarding Hausa emotive communication. These emotions occur in different contexts, to mention a few: kúkáa (crying), kwàfáa (toting), iihùu (yelling) and dàaríyáa (laughter) etc.

\subsection{The Gender Code of Emotional Expressions in Hausa}

Gender roles and socialization affect how we employ our nonverbal resources for interactional purposes. Gender code varies from one culture to another. Kelly and Comeaux (2002) maintained that "gender differences may not only surface on emotional expression alone, but even some emotions are linked to each gender. Happiness, sadness and fear are more characteristics of a female gender, while men are believed to be more characteristically angry". Every culture expresses emotions. Scholars agree that there are universal ways of expressing emotions. Ekman (1992) mentioned six universal ways of expressing emotions namely: enjoyment, anger, sadness, disgust, fear and surprise. They therefore serve as the basis of the analysis of gendered emotional expressions in Hausa, as given in the data below.

\subsubsection{Joy/Happiness Emotions}

\begin{tabular}{|l|l|l|l|}
\hline & Emotion signals & Gloss & Gender \\
\hline 1 & dàaríyáa & laughter & male/female \\
\hline 2 & gúudàa & ululation & female \\
\hline 3 & mùrmúshíi & smile & male/female \\
\hline 4 & tsállée & jumping & male/female \\
\hline 5 & wáashè bàkii & glowering & male/female \\
\hline 6 & ráwáa & dancing & male/ female \\
\hline
\end{tabular}


The emotional signals in 1-6 expressing happiness, merriment or joy are made using different channels, including the mouth, nose, hand, face and the whole body. In Hausa, these emotional signals occur at various social contexts like wedding and naming ceremonies or when something good is stated or happened in situations like the announcement of the dowry at wedding place, a marriage engagement, when conveying a bride to her matrimonial home, naming a new born baby, when offered a gift (money, car, clothing, house and a pilgrim air ticket) and when friends are involved in a chat. Therefore, these feelings are expressed by parents and children, husbands and wife/wives, friends, sisters and brothers as well as neighbours, etc.

However, out of the six happiness emotions mentioned above gúudàa is performed by females only. The descriptive epithet associated with gúuxàa is Ta roni ba a yin ki a banza... which means whenever the sound of Gúudàa is heard something good has happened or is about to happen. Invariably, it is totally a feminine affair. Gúudàa signifies the presence of women at a given place. Gúudàa therefore does not only serve to express emotions but to also convey a social message on different contexts. Some people even make the assertion that women with long noses are better at it. Likewise when a wedding is taking place, especially during the conveyance of the bride to her matrimonial home a series of gúudàa is performed all the way. The figure below depicts a woman performing gúudàa sat a wedding event as people wait for the bride to be taken to her matrimonial home.

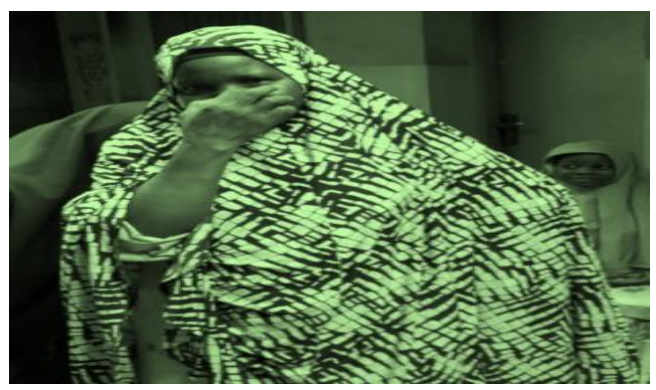

Fig 1 gúudàa (ululation)

\subsubsection{Surprise Emotions}

\begin{tabular}{|l|l|l|l|}
\hline & Emotion signals & Gloss & Gender \\
\hline 7 & káamà/ríkè habaà & Holding the chin & male/female \\
\hline 8 & káamà-bàakíi & $\begin{array}{l}\text { Holding the } \\
\text { Mouth }\end{array}$ & female \\
\hline
\end{tabular}




\begin{tabular}{|l|l|l|l|}
\hline 9 & bùuxe bàakii & Opening the mouth & male/female \\
\hline 10 & cíizòn yáatsàa & $\begin{array}{l}\text { Biting the } \\
\text { Finger }\end{array}$ & male/female \\
\hline 11 & gírgìzà kâi & Shaking the head & male/female \\
\hline 12 & dáafà kìrjíi & $\begin{array}{l}\text { Putting hand on } \\
\text { Chest }\end{array}$ & female \\
\hline
\end{tabular}

Emotional signals in this class express surprise as a result of the actions performed during a conversation among Hausa people. Surprise emotions occur as a result of information that relates to a sudden death, the delivery by an unmarried woman, unfulfilled promise among good friends and any other alarming situation. Emotion 7, káamà hábàa (holding the chin) expresses surprise. It is a gesture exclusively performed by women of the Hausa. The gesture is done by using the right hand to move and hold the chin as well as the head slightly bent to the side and the pupils are dilated just for some seconds. It could be repeated with speech intervals or silence. The right hand is mostly used to make this gesture. It resembles tàagúmíi, a gesture that signifies sadness or gloomy situation. What differentiates the two is that in tàgúmíi the open palms are used to support the sides of the face. The figure 2 below indicates a woman and a girl who are making a Hausa snack, funkaso. The process of making it requires the use of a rising agent. Ummi starts frying the funkaso and then she realises that the dough is not rising and calls the attention of Murja, who exhibits surprise by a kaámà-hábàa.

1 Ummi: Anti Murja, zo zo ki gani

Aunty, come quickly and see.

2 Murja: (walks towards the kitchen)

3 Ummi: Kalli ki gani bai tashi ba fa.

Take a look, the dough has not risen.

Murja: (uses her hand to hold her chin while staring at the frying fan on fire while and shaking her hand). Observe from the figure 2 below: 


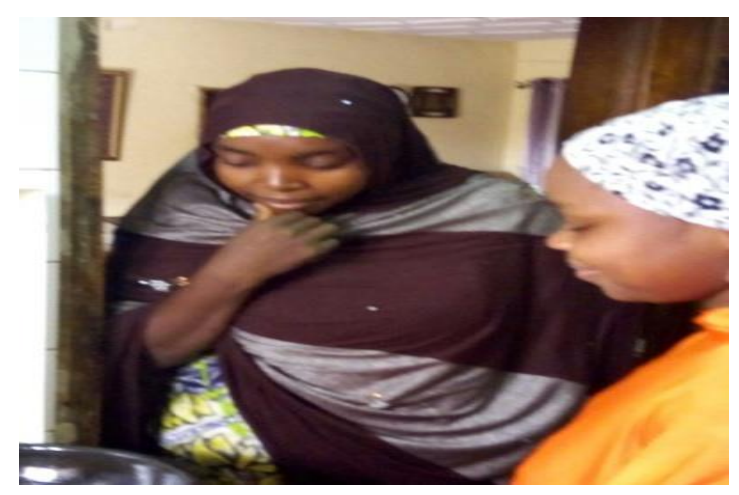

Fig 2 kaámà-hábàa (holding the chin)

Then, Emotions 8 and 12 are feelings of surprise which are performed by females and Emotion 11, performed by males whereas 9- 10 are performed by both genders (male and female) based on the data collected.

\subsubsection{Sadness/ Anger Emotional Expressions}

\begin{tabular}{|l|l|l|l|}
\hline & Emotion signals & Gloss & Gender \\
\hline 13 & hádà-kâi-dà-gúiwàa & A sitting posture & male \\
\hline 14 & kúukáa & crying & male/female \\
\hline 15 & cìizón léebèe & biting the Lips & male/female \\
\hline 16 & tsàakíi & hissing & male/female \\
\hline 17 & mùzùurái & $\begin{array}{l}\text { Silent } \\
\text { contemptuous stare }\end{array}$ & male \\
\hline 18 & tàagúmíi & sadness/dejection & male/ female \\
\hline
\end{tabular}

Emotions13-18 expressed sadness or anger via facial expressions, vocalic and postures. These feelings can be applicable at different contexts in Hausa social exchanges. Most often, death announcement, fire disaster, unwanted pregnancy, loss in election, missing a child, flood, duping and divorce are some of the reasons behind exhibiting the sadness gestures. As a result of the above occurrences, victims and/or their families and well wishers can express emotions either by means of facial expression, vocalic or posture cues, depending on the gesturer, with whom he is interacting, and context. Emotions in this group are performed by both genders in Hausa society. Figure 2 below is an instance of a sad emotional expression. 


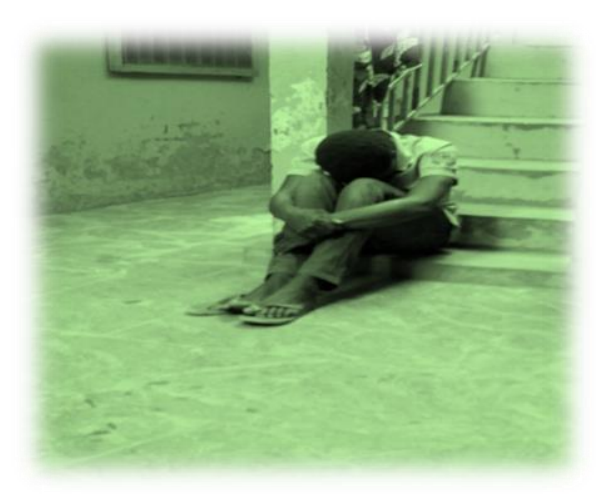

Fig 3 hádà-kâi-dà-gúiwàa (Sinking the Head in between the knees)

Hausa men exhibit sadness through hádà-kâi-dà-gúiwàa (sinking the Head in between the knees) which involves sitting commonly on the floor and sinking the head in between the knees. Apart from showing sadness, the gesture communicates a dire need for sympathy. When a person loses his father or an elder brother that is responsible for his welfare, he may depict this gesture, so that people may sympathize with him. Moreover, this gesture is marred with regret over a wrong doing the gesturer must have been reprimanded about. The person performing this gesture usually isolates himself. In figure 2 above, the gesturer performs hádà-kâidà-gúiwàa and the motive behind the gesturer is that he has failed his Jamb examination for the third time in a row. I was informed that he has been cautioned several times to study hard for him to be able to scale through but he failed to heed the advice. This gesture is usually exhibited independent of speech as the gesturer is often too disappointed for words and hence isolated himself.

\subsubsection{Fear Emotions}

\begin{tabular}{|l|l|l|l|}
\hline & Emotional signals & Gloss & Gender \\
\hline 19 & ráwár jiḱí & shivering & male/female \\
\hline 20 & kùrúurúwàa & wailing & male/female \\
\hline 21 & kaárè fúskaà & $\begin{array}{l}\text { Covering the face } \\
\text { with the hand }\end{array}$ & male/female \\
\hline 22 & íihùu & screaming & male/female \\
\hline 23 & záarè ìdòo & glowering & male/female \\
\hline 24 & $\begin{array}{l}\text { ràawár bàaki } \\
\text { /káfàa }\end{array}$ & $\begin{array}{l}\text { mouth or leg } \\
\text { shivering }\end{array}$ & male/ female \\
\hline
\end{tabular}

Fear emotional signals occur in Hausa society as a result of disaster incidents (a fire, bomb blast, ghastly accident, etc.). Emotional signals 19-24 are employed in 
Hausa by both genders to express their feelings when a disaster or incident happens. Figure 4 below is an instance fear emotional expression:

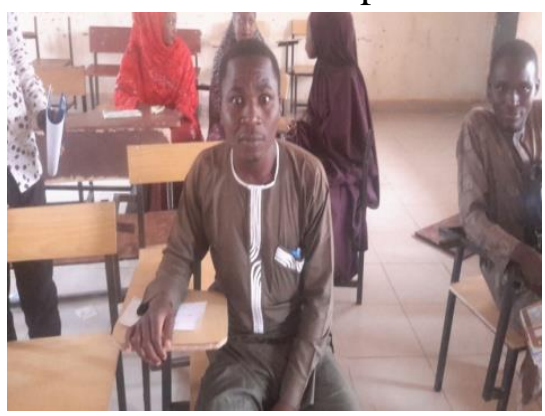

Fig 4 záarè ídóo (glowering)

4 Teacher: Za mu yi test yau

We have a test today

5 Student: (glowered while looking straight at the teacher) Ba mu da ke yau

You are not on our time-table today.

\subsubsection{Disgust/ Contempt Emotional Expressions}

\begin{tabular}{|l|l|l|l|}
\hline & Emotion signals & Gloss & Gender \\
\hline 25 & tóoshèe háncíi & $\begin{array}{l}\text { Blocking the nostril } \\
\text { with the index finger } \\
\text { and thumb. }\end{array}$ & female \\
\hline 26 & tóofár dà yáawúu & $\begin{array}{l}\text { spitting } \\
\text { Saliva }\end{array}$ & female/male \\
\hline 27 & táabè-bàakíi & mouth protruding & female \\
\hline 28 & júuy báayáa & turn the back & male/female \\
\hline 29 & kàawár dà kâi & looking away & male/female \\
\hline 30 & tsàakíi & hissing & male/ female \\
\hline
\end{tabular}

Disgust or contempt emotions are expressed to show hatred or disregard. They are performed during conversation mostly replacing utterances or words. We can observe from the Table above that 25- 28 are expressed mostly by females, while 28-30 are expressed by both males and females. 


\subsubsection{Modesty Emotional Expressions}

\begin{tabular}{|l|l|l|l|}
\hline & Emotion signals & Gloss & Gender \\
\hline 31 & sóosà-kéeyàa & $\begin{array}{l}\text { Scratching the back } \\
\text { of the neck }\end{array}$ & male \\
\hline 32 & múrzà-yáatsúu & $\begin{array}{l}\text { Playing with the } \\
\text { fingers }\end{array}$ & male/female \\
\hline 33 & Súnkúyár dà kâi & $\begin{array}{l}\text { Lowering the } \\
\text { Head }\end{array}$ & male/female \\
\hline 34 & yàakée & grimace & male/female \\
\hline 35 & rúfè fúskàa & Covering the face & female \\
& & with the hands & \\
\hline 36 & mùrmúshíi & smile & female \\
\hline
\end{tabular}

The instances of nonverbal cues that express modesty or what is known as kúnyàa in Hausa are given in 31-36. Usually kúnyàa is associated with the female gender, even though males express such feeling too. The instance in 31 is exclusively used by Hausa males, while $35 \& 36$ are female specific expressions. However, 32-35 are expressed by both males and females.

Kúnyàaa is regarded as a code of conduct in Hausa. Therefore lack of it is referred to as rashin kúnyàa. Also, when someone is involved in any act contrary to Hausa norms for example, delivering a bastard child, pregnancy before marriage and fornication, etc, the act is àbín kúnyàa. Therefore, we can say that kúnyàa is positive while abin kúnyàa (shameless act) or rashin kúnyàa (not being bashful) has a negative connotation. The following examples show how modesty is used in various contexts. 


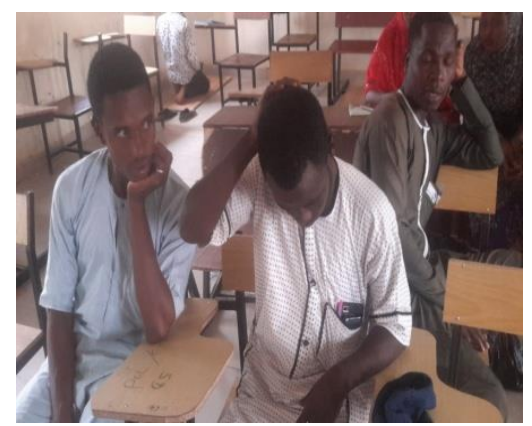

Fig 5 sóosà-kéeyàa (scratching the rear head)

6 Teacher: ku kawo assignment din ku.

Submit your assignments.

7 Student: Na manta tawa a gida.

I forgot mine at home.

9 Teacher: Ba ka yi ba ke nan, kana Class Rep amma ba ka son yin assignment.

You have not done it, you are the class rep and still you dont like doing your assignments.

10 Student: (Lowered his head and scratched the back of his neck).

\subsection{Discussion}

Conversational analysis allows for a close scrutiny of social interactions. Our main concern is the emotional expressivity of Hausa males and their female counterparts. Turn-taking allows for the pursuit of the stable trajectories of actions and responsive actions (See Schegloff 1988:98-99) in social interactions. Our data show emotional expressions serving as feedback, as demonstrated in some signals. Moreover, since we are more concerned with the communicative aspect of emotional expressions we limited our study to only the 'affect emblems'. We call them affect emblems as in Scherer (1994) because their meaning are known and are used by Hausa people to express emotions. They fulfil all the requirements proposed by Ekman \& Freisen (1972:357) and Johnson et al (1975) governing particular instances of behaviour to be regarded as a visual emblem. We even extended the term to cover other non-visual behaviours. The requirements are:

1. It must have a verbal translation consisting of a word or two or an expression.

2. All or nearly all of the members of a subgroup, class, subculture or culture must know its meaning. 
3. It must be used consciously with the intention of conveying item of information to another person.

4. The sender generally assumes responsibility for the production of the emblem.

When we study gendered emotional expressions of the Hausa, we understand that gender display rules have an overwhelming impact on social interactions dictating when where and how to portray emotional expressions. Gender display rules are learned right from early childhood exuberating through adult years. Due to gender display rules, Hausa women are banned from showing affection to their husbands and even children are expected publicly to show kúnyàa and kawaici. Gender differences in some instances manifest themselves in the way gestures are used and not solely on the selection of emotional gestures. For instance, dàariyá is an emotional expression of happiness common to all genders.

However, Ekman (1993) enquires whether there could be emotions without the face. This paper confirms that in Hausa the face is the primary site for the expression of emotions. However, other resources, such as posture, bodily cues and vocalic cues, are similarly employed, as aptly demonstrated in the paper.

Context is equally significant in making meaning out of an emotional expression. For example, kuukaa (crying) can be applied to express sadness or joy, depending on the circumstance.

In a nutshell, some emotional expressions such as káamà-hábàa (holding the chin), dáafà kírjii (hand on chest), tóoshè háncii (covering the nose), rufè fuskàa (covering the face), etc are used by females while others like hádà-kâi-dà-gúiwà (Sinking the head in between the knees), Sóosà-kéeyàa (scratching the rear head), mùuzùrài (silent contemptuous stare) are male specific. Both genders use expressions like kúukáa (crying), cìizón léebèe (biting the lip), tsàakíi (hissing) and iihùu (shouting).

\subsection{Conclusion}

The expression of emotion is vital to any given social interaction. Arguably, not only what the speaker says but how he says it contributes to meaning making. The listener also depends on emotional expressions to reach out to the mind of the speaker in order to make sense of the message received. Not all the emotional expressions in Hausa are used to accompany speech. Most of them stand as independent gestures, and explain why they are labelled as 'affect emblems, which, in turn differentiate the gender of the interactants. Emotional expressions can also be expressed through other means aside from the facial. Consequently, the emotions of a person can be picked out even from a phone conversation through vocalic cues. Virtually, gender determines the use of emotional expressions in Hausa. 


\section{References}

Adler, B. R \& Proctor II, F.R (2011). Looking Out Looking in. USA: Wadsworth.

Azare, M.A (2014) Facial Communication in the Context of Hausa Culture and Metaporical Expressions. Bayero Journal of Linguistics. Vol 1 No 1. Kano: Bayero University Press.

Ekman, P. (1992). An Arguement for Basic Emotions. Cognition and Emotion, 6(34) pp. 169-200

Ekman, P. (2004). Emotional and Conversational Nonverbal Signals. In Larrazabal, M. And Miranda, L., (eds) Language, Knowledge and Representation. Pp. 3950. Neitherland: Kluwer Acadamic Publishers.

Ekman, P., \& Friesen, W. V. (1969). The Repertoire of Nonverbal Behavior: Categories, Origins, Usage, and Coding. Semiotica, 1 pp. 49-98.

Ekman, P., Freisen, W. V. (1972). Hand movements. The Journal of Communication. Vol 22 pp. 353-374

Hochschild, A. R. (1990). Gender Codes in Women's Advice Books. In Riggins, S. H. (ed) Beyond Goffman: Studies on Communication, Institution and Social Interaction. Pp. 277-294. New York: Mutton De Gruyter

Johnson, Ekman \& Freisen (1975). Communicative Body Movements: American Emblems. Semiotica, 15 (4) pp. 335-353.

Kelly, J.R and Hutson Comeaux, S.L. (2002) Gender Stereotypes of Emotional Reactions: How we Judge Emotion as Valid. Sex Roles. 47 pp. 1-10

Muazu, A. (2013). Body Language as a Social Dialect in Hausa Culture. In Ndimale, O. M, Ahmad, M, \& Yakasai, H. M. (eds) Multi Lingual Society: A Festschrift for Abubakar Rashid.

Olofson, H. (1966) Hausa Language about Gesture. Anthropological Linguistics. Vol 16 No 1 pp. 25-39

Pawlak, N. (2014) Women and Man in Hausa Language and Culture. In Pawlak, N., Siwierska, E. \& Will, I. (ed) Hausa Chadic Studies: In Honour of Professor Stanislaw Pilaszewicz. Warsawa: Elipsa.

Pepin, N. (2008). Studies on Emotions in Social Interactions. Bulletin Suisse de Linguistique Appliquee. 88 pp. 1-18 
Perakyla, A. \& Sorjonen, M. (2012). Emotion in Interaction. London. Oxford University Press.

Ruusuvuori, J. \& Perakyla, A (2009). Facial and Verbal Expression in Assessing Stories and Topics. Research on Language and Social Interaction. 42(4). Pp 377-394

Scarantino, A. (2017) How to Do Things With Emotional Expression: The Theory of Affective Pragmatics. Psychological Inquiry, 28:2-3 165-185. Retrieved on $1^{\text {st }}$ August, 2017 From www.ict.usc.edu

Schegloff, E. A. (2006). Goffman and the Analysis of Conversation in Ervin Goffman: Exploring the Interactional Order, eds P. Drew \& A. Wootton pp 89135 Cambridge, Polity Press.

Scherer, R. S. (1994). Affect Bursts. In Stephanie H. M., Van Goozen N. E. Van de Poll and J. A. Sergeant (ed). Emotions: Essays on Emotion Theory. Pp. 161-193.

Will, I. (2009) Cultural Aspects of Nonverbal Code. In Pawlak, N. (ed). Hausa Codes and Rituals of Emotions in Asian and African Cultures, 252-265 Warzawa: Elipsa.

Will, I. (2011) Function and Meaning of Symbolic Gestures in Hausa Films. In Baldi \& Yakasai (ed). Proceedings of the $3^{\text {rd }}$ International Conference of Hausa Studies: African and European Perspectives. Univasita degli Studi di Napoli "L'Oreintale.

Will, I. (2015). Gestures and Indirect Statement as a means of Expressing Emotions and Opinions among Hausa Women, In G.C Batic \& Baldi (eds) Selected Proceeding of the Symposium on West African Languages, 233-248. NaplesUniversita degil Studi di Naploli 'Li orientale.

Yakasai, H. M. (2014) Gestures as Negative and Emphatic Markers in Hausa. In Pawlak, N., Siwierska, E. \& Will, I. (eds) Hausa Chadic Studies: In Honour of Professor Stanislaw Pilaszewicz. Elipsa 